\title{
Octreotide for enterocutaneous fistulas of Crohn's disease
}

\author{
A Lavy $M D^{1}, K^{2}$ Yasin $M D^{2}$
}

A Lavy, K Yasin. Octreotide for enterocutaneous fistulas of Crohn's disease. Can J Gastroenterol 2003;17(9):555-558.

Crohn's disease is a chronic, life-long disease and has many troublesome complications. Fistulas are a part of Crohn's disease, and although there are many therapeutic modalities used in treating these fistulas they are only partially successful. As we are still very far from being able to cure it, the aim is to improve the patients' quality of life and to reduce the iatrogenic harm that may be caused by various treatment modalities. Somatostatin is an inhibitor of intestinal secretion and has been used to treat pancreatic and surgical fistulas. Therefore, we decided to treat enterocutaneous fistulas using somatostatin.

METHODS: Five patients with Crohn's disease were treated with four daily injections of $300 \mu \mathrm{g}$ octreotide. The total period of treatment was eight weeks.

RESULTS: Closure of fistulas was achieved in four of the five patients.

CONCLUSION: Somatostatin may have a role in treating Crohn's disease enterocutaneous fistulas and may prevent surgery or prolonged immunosuppressive therapy.

Key Words: Crohn's disease; Enterocutaneous fistulas; Octreotide

Cistulas are a part of Crohn's disease presentation. They are

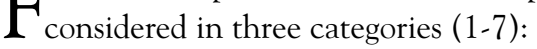

1. Benign or innocent;

2. Mild or "nuisance"; and

3. Complicated, associated with an abscess or intractable

bowel disease.

Fistulas of the first category usually do not require treatment. Fistulas of the third category are mostly treated surgically (8). As for the second category, there are many therapeutic modalities with only partial success. Included in this category are enterovesicular, enterocutaneous and enterocolic fistulas. Most are treated with antibiotics and immunosuppressive drugs (9-13) for many months to achieve any result. For most of modalities the response rate is up to $60 \%$, but relapse is common (14). Infliximab was shown to be effective in $67 \%$ of cases (15) but again, relapse rate is high because many patient develop tolerance or side effects. Results are somewhat better with combination therapy, but costs and side effects are higher.

It was demonstrated in animal models that regulatory peptides and cytokines play a role in the mucosal inflammatory

\section{L'octréotide pour traiter des fistules entérocu- tanées de la maladie de Crohn}

La maladie de Crohn est une maladie chronique et permanente qui s'accompagne de nombreuses complications pénibles. Les fistules font partie de la maladie de Crohn, et bien qu'il existe de nombreuses modalités thérapeutiques pour les soigner, celles-ci ne sont que partiellement efficaces. Comme nous sommes encore très loin de pouvoir guérir cette maladie, il faut viser à améliorer la qualité de vie des patients et à réduire les dommages iatrogènes susceptibles de découler de diverses modalités de traitement. La somatostatine est un inhibiteur de la sécrétion intestinale et est utilisée dans le traitement des fistules pancréatiques et chirurgicales. C'est pourquoi nous avons décidé de traiter les fistules entérocutanées à la somatostatine.

MÉTHODOLOGIE : Cinq patients atteints de la maladie de Crohn ont été traités au moyen de quatre injections quotidiennes de $300 \mu \mathrm{g}$ d'octréotide. Le traitement a duré huit semaines.

RÉSULTATS : Les fistules se sont refermées chez quatre des cinq patients.

CONCLUSION : La somatostatine peut jouer un rôle dans le traitement des fistules entérocutanées de la maladie de Crohn et peut prévenir une chirurgie ou une thérapie immunosuppressive prolongée.

Gastroenterology Unit, ${ }^{1}$ Bnai Zion Medical Center, ${ }^{2}$ Rambam Medical Center, Haifa, Israel

Correspondence: Dr A Lavy, Gastroenterology Unit, Bnai Zion Medical Centre, Haifa, Israel. Telephone +972-4-8359426,

fax+972-4-8201455, e-mail lavya@netvision.net.il

Received for publication January 6, 2003. Accepted July 7, 2003 
TABLE 1

Please supply a title for this table

\begin{tabular}{|c|c|c|c|c|c|c|c|c|}
\hline Patient & Age (years) & Sex & $\begin{array}{l}\text { Disease } \\
\text { duration }\end{array}$ & $\begin{array}{l}\text { Disease } \\
\text { location }\end{array}$ & $\begin{array}{l}\text { Fistula } \\
\text { location }\end{array}$ & Cause & Treatment & Outcome \\
\hline$\overline{S K}$ & 17 & Female & 2 years & Terminal ileum & Abdomen & $\begin{array}{c}\text { Postabscess } \\
\text { drainage }\end{array}$ & $\begin{array}{l}\text { Mesalazine } \\
\text { Ciprofloxacin } \\
\text { Metronidazole }\end{array}$ & $\begin{array}{l}\text { Closed } \\
\text { reopened } \\
\text { surgery }\end{array}$ \\
\hline MR & 50 & Male & 30 years & $\begin{array}{l}\text { Terminal ileum } \\
\text { Right colon }\end{array}$ & Abdomen & Postoperative & $\begin{array}{l}\text { Mesalazine } \\
\text { Metronidazole } \\
\text { 6-mercaptopurine } \\
\text { Ciprofloxacin }\end{array}$ & Closed \\
\hline AN & 40 & Male & 26 years & Small and large bowel & Abdomen & Spontaneous & $\begin{array}{l}\text { Metronidazole } \\
\text { Ciprofloxacin }\end{array}$ & Closed \\
\hline SM & 37 & Male & 1 year & Ileum & Abdomen & $\begin{array}{l}\text { Post abscess } \\
\text { drainage }\end{array}$ & $\begin{array}{l}\text { Ciproxin } \\
\text { Metronidazole } \\
\text { Mesalazine }\end{array}$ & $\begin{array}{l}\text { Closed } \\
\text { reopened one } \\
\text { year later. } \\
\text { surgery }\end{array}$ \\
\hline TB & 45 & Male & 6 years & $\begin{array}{l}\text { Terminal ileum } \\
\text { Rectum }\end{array}$ & Gluteal & Spontaneous & $\begin{array}{l}\text { 6-mercaptopurine } \\
\text { Metronidazole }\end{array}$ & Closed \\
\hline
\end{tabular}

before. The patients were taught to subcutaneously inject $300 \mu \mathrm{g}$ of octreotide four times daily. The dose was chosen according to previous partially successful reports for surgical fistulas (27-29). To demonstrate effect, we decided to give a relatively high dose in this pilot study. The patients were seen every week by the same physician and fistula was assessed according to pads used by the patient.

Other medications, including antibiotics, were not allowed. The total period of treatment was eight weeks. Results are shown in Table 1 and case reports are described below.

\section{CASE PRESENTATIONS}

Case one

A 17-year-old girl developed Crohn's disease of the terminal ileum at the age of 15 . She was well on mesalazine for two years and then developed fever and a red tender spot in the right groin. Computerized tomography revealed inflamed small bowel loops with an abscess formation. This was punctured for drainage and later an enterocutaneous fistula developed. The patient was treated for three months with corticosteroids, ciprofloxacin, metronidazole and mesalazine, without response. She was then put on total parenteral nutrition for bowel rest, and after an additional two weeks, injections of somatostatin were added. Four weeks of treatment closed the fistula. Two weeks later an upper gastrointestinal series was done, following which the fistula reopened. She was sent for surgery and had terminal ileectomy. Since then, she has been doing well solely on mesalazine.

\section{Case two}

A 50-year-old man had Crohn's disease for 30 years. Five years after diagnosis, he had a terminal ileectomy and a right hemicolectomy due to an obstructive disease. Twelve years later he had another resection of the preanastomotic intestine for the same reason, following which an enterocutaneous fistula developed. He was treated with mesalazine, metronidazole, corticosteroids and 6-mercaptopurine for six months without improvement. Somatostatin was then added.
The fistula closed after five weeks and has remained closed for 24 months. The patient is currently taking mesalazine and 6-mercaptopurine.

\section{Case three}

A 40-year-old man was suffering from diffuse Crohn's disease for 26 years. At the age of 14 years he had a subtotal colectomy, followed by a short remission.

A year later he was sick again, necessitating prolonged periods of corticosteroids and mesalazine. An attempt to give him 6-mercaptopurine led to severe neutropenia. There was no response to methotrexate. At 21 years of age he underwent his second surgery, a gastrojejunostomy, because of obstruction due to Crohn's duodenal involvement.

Two years later he developed severe perianal disease and twice had perianal abscess drainage. At that time, he already had an anastomotic stricture, which was dilated at colonoscopy using through-the-scope balloon dilators. He developed an enterocutaneous fistula, originating in the preanastomotic ileum. He did not respond to three months of treatment with metronidazole and corticosteroids and was therefore started on somatostatin injections. After three weeks, the fistula closed. He completed eight weeks of treatment. The fistula has remained closed for 19 months, and the patient is currently taking mesalazine and intermittent corticosteroids.

\section{Case four}

A 37-year-old man was diagnosed as suffering from Crohn's disease involving most of the ileum. He was treated with mesalazine, but a year later he was hospitalized with fever and pain. Computerized tomography revealed abscess formation above the bladder. This was drained and he received antibiotics, corticosteroids and mesalazine. Removal of the drain resulted in ileocutaneous fistula formation. After two months of metronidazole, somatostatin injections were added and the fistula closed within two weeks. The patient completed eight weeks of treatment. He was maintained on mesalazine, but a year later his disease worsened and the fistula reopened. At 
that time he was referred for surgery and had a resection of the cecum and a segment of distal ileum. He recovered uneventfully.

\section{Case five}

A 45-year-old man was suffering from Crohn's disease for six years. He had involvement of the terminal ileum and rectum together with an active perianal disease. He was treated with mesalazine, metronidazole and 6-mercaptopurine for six months, but developed a cologluteal fistula.

He was started on somatostatin injections and his gluteal fistula closed after six weeks. The patient complained of worsening diarrhea, but was able to complete eight weeks of treatment. The fistula has remained closed for twelve months, and the patient is currently taking mesalazine and 6-mercaptopurine.

\section{Patient compliance and side effects}

The patients were taught to inject themselves with somatostatin four times daily, and complied very well. Most of them tolerated the treatment well. Patient five complained of increased stool frequencies during treatment but he still completed eight weeks of therapy.

Acknowledging the reported complication of gallstones in patients receiving somatostatin (27-28), all patients were followed by an ultrasonographic examination. None developed gallstones. However, because of this feared complication, we chose not to prolong treatment beyond eight weeks.

\section{DISCUSSION}

Somatostatin is a cyclic peptide, consisting of 14 amino acids (31) with a variety of physiological activities. It is a neurotransmitter in the central nervous system and regulates growth hormone and thyrotropin release.

In the gastrointestinal tract, somatostatin has a mainly inhibitory action on glandular secretion, smooth muscle contractility, absorption of nutrients and activation of immune cells, as well as pancreatic secretion (34-35). It has been clearly shown to be present in inflammatory tissues.

Because of these qualities, somatostatin may be suitable for treating high to moderate output fistulas, which are troublesome to the patient. Several studies reported favourable results for both small bowel and pancreatic postoperative fistulas (36-38). In 1993, Torres et al (39) reported a double-blind study with 40 patients which found no significant difference in the percentage of fistula closures, following somatostatin treat-

\section{REFERENCES}

1. Givel J, Hawker P, Allan R, et al. Entero-enteric fistulas complicating Crohn's disease. J Clin Gastroenterol 1983;5:321-3.

2. Greenstein AJ, Sachar DB, Tzakis A, Sher L, Heimann T, Aufses AH Jr. Course of enterovesical fistulas in Crohn's disease. Am J Surg 1984;147:788-92.

3. Janowitz HD. The problems of fistulas. In: Janowitz HD, ed. Inflammatory Bowel Disease. A Personal View. Chicago: Year Book Medical Publishers, 1985:105.

4. Radcliffe AG, Ritchie JK, Hawley PR, Lennard-Jones JE, Northover JMA. Anovaginal and rectovaginal fistulas in Crohn's disease. Dis Colon Rectum 1988;31:94-9.

5. Greenstein AJ, Kark AE, Dreiling DA. Crohn's disease of the colon. I. Fistula in Crohn's disease of the colon, classification presenting features and management in 63 patients. Am J Gastroenterol 1974;62:419-29.

6. Kornbluth A, Sachar DB, Salomon P. Crohn's disease. In: Sleisenger MH, Fordtran JS, eds. Gastrointestinal and Liver Disease, 6th ed. Philadelphia: Saunders, 1998:1715. ment, compared with total parenteral nutrition. However, somatostatin shortened the time required for closure and reduced morbidity. In Crohn's disease, Skvarilova et al (40) reported results of intravenous somatostatin combined with total parenteral nutrition for the treatment of fistulas. The success rate was $37.5 \%$. There are no details regarding dosage or duration of treatment. The authors also used histoacryl sealant as an additional treatment.

As Crohn's disease fistulas are related to disease activity, it may well be that somatostatin's favourable influence could be partially related to its role as an inhibitor of immune functions and, thus, act as a regulator of mucosal inflammation (41). Recent studies show that somatostatin acts on T-cells to regulate interferon- $\gamma$ release $(42,43)$, inhibits TNF- $\alpha$ in cell lines and regulates cytokine expression in human colonic epithelial cells (44), suppressing proinflammatory cytokines, such as monocyte chemoattractant protein-1, interleukin (IL)-8 and stimulating inhibitory cytokine IL-10.

The decreased concentration of somatostatin in inflamed colonic mucosa of inflammatory bowel disease patients could also suggest a role for it in the inflammatory process, which may explain in part our favourable results.

A paper by Present (14) summarized the current experience with Crohn's disease fistulas. The success rate with most therapies is approximately $60 \%$ with high recurrence and is involved with both high cost and high incidence of side effects.

\section{CONCLUSIONS}

Fistulas are common and occur in up to $35 \%$ of patients with Crohn's disease. They are very troublesome to the patient and markedly reduce quality of life; therefore, there should be a place for less toxic therapy such as somatostatin, whether as a bridge to surgery or while considering cytotoxic drugs. It may also be used for relatively inactive disease except for a fistula as a single symptom.

In a pilot study, we treated five Crohn's disease patients with enterocutaneous fistulas, giving relatively high doses of octreotide, the potent analogue of somatostatin (45), and four of them responded.

We suggest that somatostatin may have a role in treating Crohn's disease enterocutaneous fistulas and may prevent surgery or prolonged immunosuppressive therapy. Longer treatment should be considered as well as long-acting somatostatin analogues in an aim to achieve better results.

7. Wilton PB, Goldberg SM. Perianal disease. In: Bayless TM, ed. Current Managment of Inflammatory Bowel Disease. Philadelphia: BC Decker, 1989:298.

8. Sohn N, Korelitz BI, Weinstein MA. Anorectal Crohn's disease. Definitive surgery for fistulas and recurrent abscess. Am J Surg 1980;139;394-7.

9. Korelitz BI, Present DH. Favorable effects of 6 mercaptopurine in fistulae of Crohn's disease. Dig Dis Sci 1985;30:58-64

10. Present DH, Korelitz BI, Wische M, et al. Treatment of Crohn's disease with 6MP. A long term randomized double-blind study. N Eng J Med 1980;302:981-7.

11. Jakobovits J, Schuster MM. Metronidazole therapy for Crohn's disease and associated fistula. Am J Gastro 1984;79:533-40.

12. Lichtiger S, Present DH. Cyclosporine therapy in the treatment of Crohn's perianal fistulous disease. J Autoimmunol 1991;2:A29. (Abst)

13. Smith MB, Hanauer SB. Rapid closure of Crohn's disease fistulae 
with intravenous cyclosporin A (CyA). Am J Gastroenterol 1991;86:1376. (Abst)

14. Present DH. Crohn's fistula: Current concepts in management. Gastroenterology 2003;124:1629-35.

15. Present DH, Rutgeerts $P$, Taragan $S$, et al. Infliximab for the treatment of fistulas in patients with Crohn's disease. N Eng J Med 1999;340:1398-405.

16. Calam J, Gatei MA, Domin J, et al. Regional differences in concentrations of regulatory peptides in human colon mucosal biopsy. Dig Dis Sci 1989;34:1193-8.

17. Mayer EA, Raybould H, Koelbel C. Neuropeptides, inflammation, and motility. Dig Dis Sci 1988;33:71S-7S.

18. Dawson J, Bryant MG, Bloom SR, Peters TJ. Gastrointestinal regulatory peptide storage granule abnormalities in jejunal mucosal diseases. Gut 1984;25:636-43.

19. Blum AM, Elliot DE, Metwali A, Li J, Qadir K, Weinstock JV. Substance $\mathrm{P}$ regulates Somatostatin expression in inflammation. J Immunol 1998;161:6316-22.

20. Reubi JC, Laissue J, Waser B, Horisberger U, Sacher JC. Expression of somatostatin receptors in normal, inflamed, and neoplastic gastrointestinal tissues. Ann NY Acad Sci 1994;33:122-37.

21. Guandalini S, Kachur JF, Smith PL, Miller RJ, Field M. In vitro effects of somatostatin on ion transport in rabbit intestine. Am J Physiol 1980;38:G67.

22. Dharmsathaphorn K, Racusen L, Dobbins JW. Effects of somatostatin on ion transport in the rat colon. J Clin Invest 1980;66:813-20.

23. Dharmasathaphorn K, Sherwin RS, Dobbins JW. Somatostatin inhibits fluid secretion in the rat jejunum. Gastroenterology 1980;78:1554-8.

24. Kvols LK, Moertel CG, O'Connel MJ, et al. Treatment of the malignant carcinoid syndrome. Evaluation of a long acting somatostatin analogue. N Eng J Med 1986;315:663.

25. Maton PN, O'Dorisio TM, Howe BA, et al. Effects of a long acting somatostatin analogue (SMS 201-995) in a patient with pancreatic cholera. N Eng J Med 1985; 312:17.

26. Harris AG. Octreotide in the treatment of the gastrointestinal tract. Drug Invest 1992;4:1-54.

27. Acromegaly Therapy Consensus Development Panel. Benefits versus risks of medical therapy for acromegaly. Am J Med 1994;97:468-73.

28. Chanson P, Weintraub BD, Harris AG. Octereotide therapy for thyroid-stimulating hormone-secreting pituitary adenomas: A follow-up of 52 patients. Ann Intern Med 1993;119:236-40.

29. Krulich L, Dhariwal APS, McCann SM. Stimulatory and inhibitory effects of purified hypothalamic extracts on growth hormone release from rat pituitary in vitro. Endocrinology 1968;83:783-90.
30. Farthing MJG. Octreotide in the treatment of refractory diarrhea and intestinal fistulas. Gut Suppl 1994;3:S5-10.

31. Lamberts SWJ, Van der Lely AJ, De Herder WW, Hofland LJ. Octreotide. N Eng J Med 1996;334:246-54.

32. Buchler M, Friess H, Klempa I, et al. Role of octreotide in the prevention of postoperative complications following pancreatic resection. Am J Surg 1992;163:125-31.

33. Bassi C, Falconi M, Lombardi D, et al. Prophylaxis of complications after pancreatic surgery: Results of a multicenter trial in Italy. Digestion 1994;55(Suppl 1):41-7.

34. Patel YC. General aspects of the biology and function of somatostatin. In: Basic Clinical Aspects of Neuroscience, Vol 4. Heidelberg, Germany: Springer-Verlag, 1992. \{Editors?\}

35. Reubi JC, Waser B, Horisberger U, et al. In vitro autoradiographic and in vivo scintigraphic localization of somatostatin receptors in human lymphatic tissue. Blood 1992;82:2143-51.

36. Scott NA, Finnegan S, Irving MH. Octreotide and gastrointestinal fistulae. Digestion 1990;45(Suppl):66-71.

37. Sitges-Serra A, Guirao X, Pereira JA, Nubiola P. Treatment of gastrointestinal fistulas with Sandostatin. Digestion 1993;54(Suppl):38-40.

38. Borison DI, Bloom AD, Pritchard TJ. Treatment of enterocutaneous and colocutaneous fistulas with early surgery or somatostatin analog. Dis Colon Rectum 1992;35:635-9.

39. Torres AJ, Landa JI, Moreno-Azcoita M, Somatostatin in the management of gastrointestinal fistulas. Arch Surg 1992;127:97-100.

40. Skvarilova M, Nicakova R, Axmann K. New alternatives for the treatment of fistulas in Crohn's disease. Acta Univ Palacki Fac Med 1994;138P:29-31.

41. Jabri B, Babyyatsky M, Somatostatin receptors are expressed by intraepithelial lymphocytes and regulate T-cell activation. Gastroenterol 2000;118:A791.

42. Weinstock JV, Elliot D. The somatostatin immunoregulatory circuit present at sites of chronic inflammation. Eur J Endocrinol 2000;143:S15-9.

43. Elliott DE, Li J, Blum AM, Metwali A, Patel YC, Weinstock JV. SSTR2A is the dominant somatostatin receptor subtype expressed by inflammatory cells, is widely expressed and directly regulates T cell IFN-gamma release. Eur J Immunol 1999;29:2454-63.

44. Patel T, Ping J, Sheharyar A, Babyatsky MW. Regulation of chemocytokines by somatostatin in human colonic epithelial cell line. Gastroenterol 2000;118:A93.

45. Bauer W, Briner U, Doepfner W, et al. SMS 201-995: A very potent and selective octapeptide analogue of somatostatin with prolonged action. Life Sci 1982;31:1133-40. 


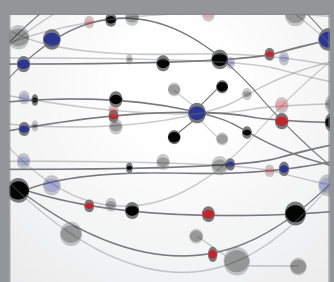

The Scientific World Journal
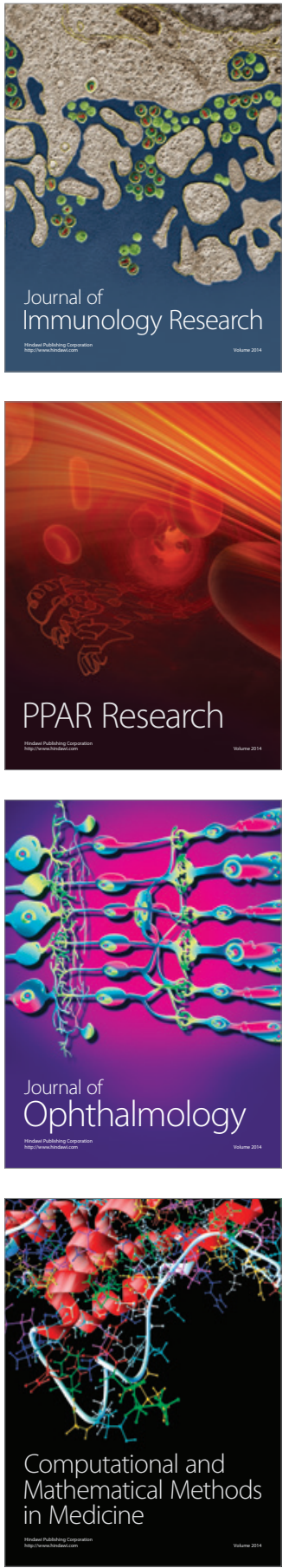

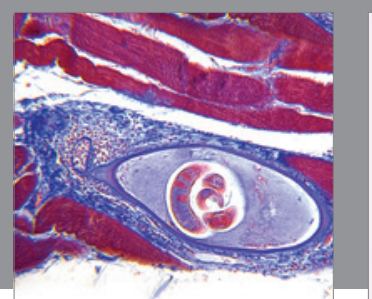

Gastroenterology Research and Practice

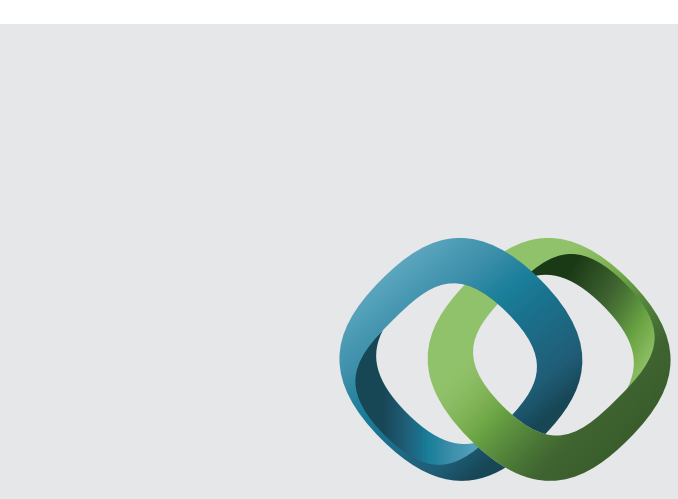

\section{Hindawi}

Submit your manuscripts at

http://www.hindawi.com
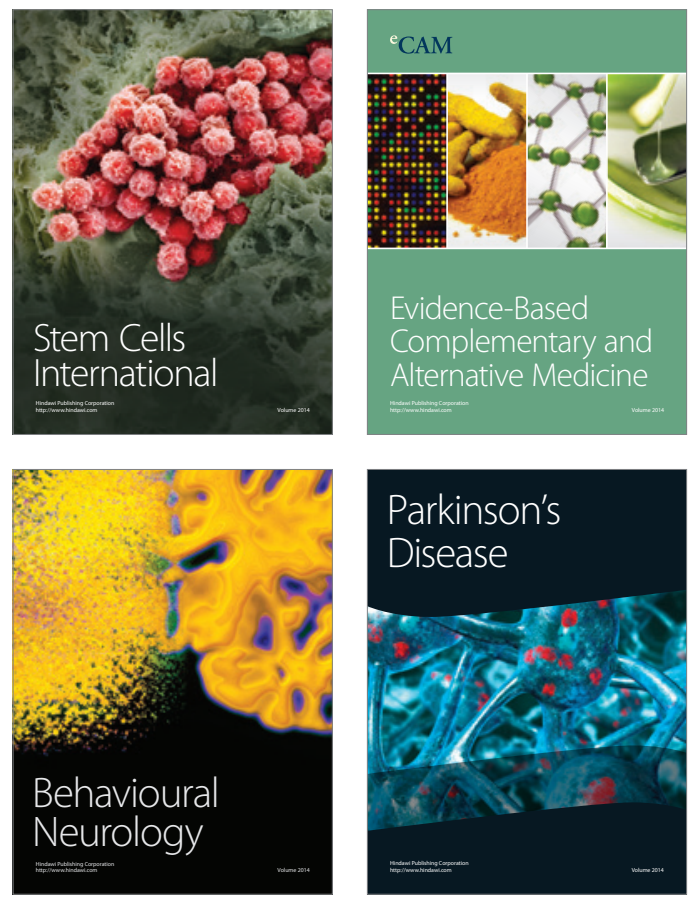
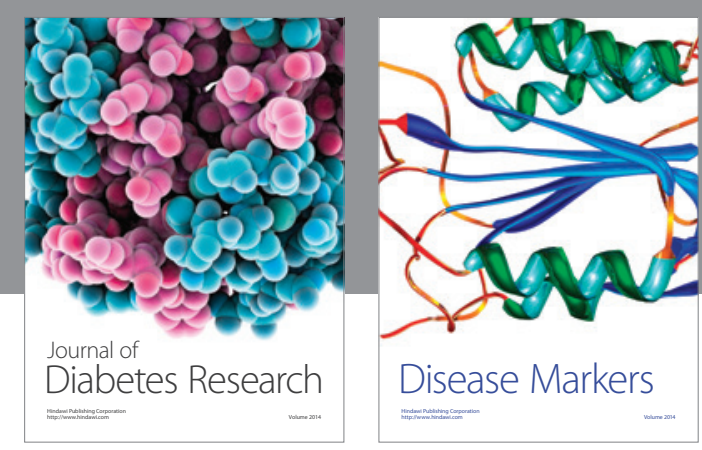

Disease Markers
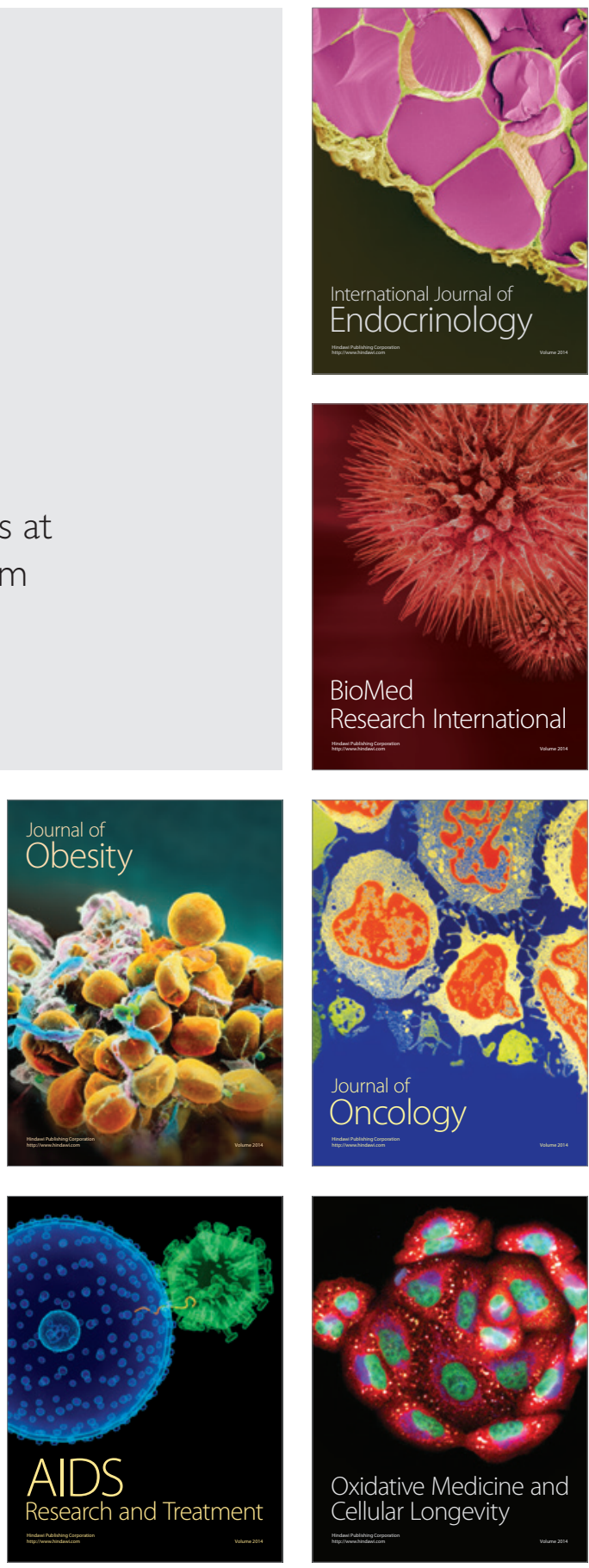